\title{
Doing Bad by Doing Good? Theft and Abuse by Lenders in the Microfinance Markets of Uganda
}

\author{
Catherine S. M. Duggan ${ }^{1,2}$
}

Published online: 17 May 2016

C) The Author(s) 2016. This article is published with open access at Springerlink.com

\begin{abstract}
Microcredit transactions in developing countries create risks for borrowers that are routinely overlooked in the literature. This paper argues that common microfinance-lending methodologies that allow lenders to collateralize loans and unilaterally collect this security create opportunities for malicious lenders to steal from clients in good standing. In places where any lender can simply call itself a "microfinance institution" (MFI), opportunistic lenders can use the halo effect associated with microfinance to encourage borrowers to make themselves unusually vulnerable to theft. Evidence of these abuses can be seen in a case study of Uganda, where theft and fraud by a small number of microfinance institutions created a large-scale crisis and contributed to a precipitous decline in trust in the financial sector as a whole. Even when it occurs only on the margins of the sector, I conclude, this type of opportunism may have problematic implications for all MFIs and undermine efforts to increase financial inclusion. This possibility provides a new impetus to consider innovative regulatory approaches for microfinance.
\end{abstract}

Keywords Microfinance - Economic development - Financial supervision - Reputation · Financial inclusion $\cdot$ Fraud $\cdot$ Africa $\cdot$ Uganda

What differentiates microcredit institutions from the informal moneylenders they were intended to replace? Conventional approaches have tended to draw a bright line between these two types of lenders: moneylenders are often characterized as greedy and abusive, able to exploit their local knowledge to profit from borrowers with few other options; microcredit institutions, in contrast, are typically characterized as being intrinsically benevolent, focused on using particular lending tactics and methodologies

Catherine S. M. Duggan

csmduggan@gmail.com

1 School of Business, African Leadership University, Kigali, Rwanda

2 Saïd Businesss School, Oxford University, Oxford, UK 
to provide vulnerable populations with access to credit - and, more broadly, motivated by an interest in expanding financial inclusion. ${ }^{1}$ Microfinance institutions are, in this conventional narrative, essentially benevolent by definition. ${ }^{2}$

Yet, in many markets, this optimistic definition of microfinance bears little resemblance to the complex and chaotic "microfinance" sector as it appears to borrowers. ${ }^{3}$ In areas where the state exerts little effective control over the microfinance sector, as is the case in much of sub-Saharan Africa and parts of South Asia, essentially anyone can hang a shingle and call himself a "microfinance institution" (MFI). In countries like Uganda, the vast majority of MFIs are local organizations and individuals who have set up MFIs as entrepreneurial ventures; there is no test of intent to do microfinance and no supervision of micro-lenders' behavior.

This paper argues that the policies and methodologies that encourage responsible MFIs to lend can also enable dishonest lenders to steal under the guise of microfinance. Insofar as contemporary microfinance is designed not only to give creditors more extrajudicial recourse over their clients but also to encourage vulnerable borrowers to engage with relatively new institutions and innovative lending methodologies, it can create an environment that is ripe for these types of abuses. Worse, as long as borrowers cannot reliably differentiate between benevolent lenders and malicious ones, the overall reputation of the entire microfinance market may rise with the activities of the former - only to fall on the abuses of the latter. As long as the opportunistic behavior of a small number of lenders can undermine trust in microfinance as a whole, then the overall costs of this malfeasance stand to go well beyond the value of the property that was actually stolen.

I explore the observable implications of this argument in the context of Uganda's microfinance sector. After years of credit promotion and laissez faire policies, Uganda has one of the deepest and most competitive landscapes for microfinance in subSaharan Africa, with little effective regulation or supervision for the vast majority of the lenders operating in the country. In this environment, some borrowers have lost savings and property in excess of what they owed, while others have had collateral seized even though they had not missed a payment or even received a loan. Malicious lenders have, moreover, been able to continue to operate for remarkably long periodsin one case more than a decade-despite well-publicized abuses and repeated efforts to shutter them. The consequences of these problems can be seen in the precipitous decline in the levels of trust that Ugandans report even for highly regulated financial institutions. Rather than spurring financial inclusion, the laissez faire expansion of microfinance in Uganda may have actually undermined trust in the sector.

This paper is organized into three main parts. I begin by discussing the existing literature and the state of the microfinance sector. Next, I argue that conventional

\footnotetext{
${ }^{1}$ Financial inclusion is typically defined as an effort to expand access to multiple forms of finance, including credit, savings, payments, and insurance. See Consultative Group to Assist the Poor (2012), p. 5.

2 "Microfinance" is often defined to implicitly or explicitly include only institutions that are licensed (or registered) by the government, that employ some versions of these joint-liability lending methodologies and that are interested in expanding access to various financial services, including credit, savings, and insurance. See, e.g., Consultative Group to Assist the Poor (2012), pp. 1-6; Ledgerwood et al. (2013), pp. 1-3.

${ }^{3}$ In an effort to reflect borrowers' experiences more closely, I define microfinance to include the activities of any institution claiming to do "microfinance" or doing business as a "microfinance institution." I use microfinance, microcredit, and microlending interchangeably, though many scholars have begun to use microfinance to refer to a wider spectrum of non-credit financial products.
} 
models of lending and microfinance ignore the risks that these transactions pose to borrowers. I go on to explore the crises and allegations of malfeasance in Uganda's microfinance market, as well as the dramatic shift in Ugandan borrowers' perceptions of these institutions. The conclusion outlines the implications of this argument and suggests one way to mitigate these issues: creating incentives for microfinance lenders to monitor and police one another to prevent bad behavior among themselves. Ironically, one way to reduce malfeasance among microfinance lenders may be to incorporate some of the familiar dynamics of collective responsibility that these lenders have long used to prevent strategic default among groups of borrowers.

\section{Background}

Microfinance is designed to encourage lending by mitigating the costs and risks of making small loans where courts are inadequate and borrowers lack collateral. Its roots lie in economic models that assume that borrowers are the only party to loans that can act opportunistically by breaking a lending contract. If borrowers default, these models suggest, then lenders generally have little recourse other than using courts to seize the defaulter's collateral. In the absence of these institutional protections, or where borrowers lack collateral that can be attached in this way, lenders can best protect themselves by rationing credit, or refusing to lend at the prevailing rate of interest. ${ }^{4}$

Classical microfinance methodologies reduce these default risks by disbursing loans to groups of borrowers (often women) and preventing them from taking additional loans until all group members have repaid. These models essentially allow lenders to outsource screening, monitoring, and collection activities to co-borrowers who can provide these functions effectively and at low cost to the institution. ${ }^{5}$ In this way, these institutions are able to tap into local knowledge, relationships, and peer pressure in ways once available only to informal moneylenders: identifying borrowers, creating incentives for repayment, and enforcing their claims against defaulters without resorting to corrupt, inefficient, or problematic courts. These models have been enormously influential: some estimates have placed the number of global microfinance borrowers at 100 million. $^{6}$

This conventional model of microfinance suggests that competition is likely to yield a number of desirable outcomes. The proliferation of MFIs may decrease interest rates, encourage innovation in lending products, increase geographic outreach, and create incentives for some institutions to redouble their focus on the very poor. ${ }^{7}$ As microfinance expands its reach, borrowers should naturally prefer to borrow from MFIs rather than informal moneylenders, driving badly run or potentially abusive

\footnotetext{
${ }^{4}$ See, e.g., Greif (2006); Wydick (2008); and Ray (1998) for discussions of these dynamics in developing countries and markets; see also Rasmusen (2007: 136-137) for a general discussion of borrowing as a onesided Prisoner's Dilemma, and Stiglitz and Weiss (1981) on credit rationing.

5 There is substantial variation in particulars such as group-formation and payment sequence.

${ }^{6}$ See Cull et al. (2009b) for an overview of the sector. Estimates of the size of the microfinance sector vary significantly. Banerjee et al. (2015) cite the Microcredit Summit Campaign, which put the number at 137.5 million borrowers in 2010; the 2014 Microfinance Barometer placed the number at 90 million in 2012, basing this calculation on MIXMarket data.

${ }^{7}$ See, Cull et al. (2011), and Cull et al. (2009a). Competition may also increase interest rates in some cases, as competition drives up the costs of screening borrowers. See Hoff and Stiglitz (1998).
} 
lenders out of the market. As long as these failed lenders are not accepting deposits or intermediating savings, then these failures may actually improve the health of the sector.

Microfinance has not been without critics. There is an ongoing scholarly debate over whether microfinance is actually responsible for the developmental gains that have been credited to it, as well as whether it is actually associated with reduced progress in outcomes such as children's education. ${ }^{8}$ Various countries, including Bolivia, Nicaragua, and Morocco, have suffered microfinance crises as the rapid expansion of the sector led to multiple borrowing and client over-indebtedness. Microfinance collection practices have come under increasing scrutiny, particularly in the wake of a 2010 crisis in the Indian state of Andhra Pradesh, in which a spate of borrower suicides was attributed to microfinance loans. In most places, neither market competition nor explicit government intervention has succeeded in eradicating moneylenders: not only are states unable to enforce their policies, argues one scholar, but also microfinance and informal moneylenders are imperfect substitutes, with social and political interests leading to various market segmentations and distortions. ${ }^{9}$

Some of the most promising work on problematic behavior by MFIs has come from qualitative research. Several scholars have detailed the gap between the benevolent goals and descriptions of microfinance and the systematically abusive and exploitative practices of microfinance agents, as well as pressure, violence, and abuse suffered by borrowers at the hands of members of their borrowing groups. ${ }^{10}$ Others have explored the degree to which microfinance relies on patriarchal mechanisms for controlling women's behavior, inducing repayment by appropriating existing cultural mechanisms for socially shaming women, and the way that existing cultural power dynamics shape patterns of financial inclusion. ${ }^{11}$

In response to these problems, policymakers, donors, and practitioners have developed guidelines for regulation and best practices in microfinance markets. Prudential regulations, including minimum capital requirements, are designed to prevent insolvency and systemic failures among financial institutions. Non-prudential regulations or "conduct of business" regulations, ${ }^{12}$ mandate consumer protections including the clear communication of loan terms to borrowers, the prohibition of discrimination in lending, interest rate caps, data protections, and ways for borrowers to lodge complaints against institutions. These guidelines also address the problem of "over-aggressive" collection practices and predatory lending, in which lenders convince relatively unsophisticated borrowers to take on debts far in excess of what they can reasonably manage. ${ }^{13}$

Yet, many observers continue to be wary of regulation. Many weigh the relatively small value of money stolen and clients cheated against the benefits of expanded financial inclusion; through this lens, the chilling effect of government regulation on credit market expansion might do more harm than good. Indeed, recent work has suggested that burdensome regulation may lead profit-driven MFIs to reduce their level

\footnotetext{
${ }^{8}$ Banerjee et al. (2015); Hulme (2007); Rippey (2007); and, more generally, Dichter and Harper (2007). See Van Rooyen et al (2012) for a comprehensive review of these issues and findings in Sub-Saharan African microfinance.

9 Tsai (2004).

${ }^{10}$ Cons and Paproki (2008); Rahman (1999); Ganle et al. (2015).

${ }^{11}$ Karim (2011); Mair et al. (2012).

${ }^{12}$ CGAP (2012), p. 14.

${ }^{13}$ See CGAP (2012), pp. 52-59; Brix and McKee (2010).
} 
of outreach, potentially undermining the goal of expanding financial inclusion. ${ }^{14}$ Another issue is that of supervision or the enforcement of regulations. In countries where governments have relatively little supervisory capacity and microfinance sectors have large numbers of otherwise unsupervised institutions, well-meaning regulations might go ignored, or, worse, contribute to a false sense of security. ${ }^{15}$

Indeed, while these consumer protection guidelines and efforts to detail abuses are encouraging, they do not address some of the key — and routinely overlooked — ways that lenders can act opportunistically. While existing models have focused on institutional failure and incompetence, they have, broadly speaking, not focused on the fundamental ways that lending contracts make borrowers vulnerable to opportunistic lenders. In fact, borrowers face risks stemming not only from the way contracts are advertised, written, and enforced, or from the risk that institutions will fail but also from the risk that lenders will break the contract to steal from their clients.

\section{Theory: Lender Opportunism and Reputational Vulnerabilities}

The conventional view of lending transactions suggests that they are one-sided prisoners' dilemmas: lenders are vulnerable to borrowers, but the reverse is not true. In fact, where institutions are absent or inadequate, both borrowers and lenders may be able to act opportunistically toward one another: borrowers can default; lenders can not only seize more than what they are entitled to after a default but also they may be able to pursue their clients unilaterally to seize their property whether or not they have actually defaulted. The institutions that support lending, then, enforce not one promise, but two: the borrower's promise to repay and the lender's promise to leave the borrower in peace as long as he does repay. ${ }^{16}$

Although microfinance was certainly not intended as a way to make poor borrowers more vulnerable to their creditors, that is often the overall effect of these lending models. By explicitly strengthening protections for lenders, these strategies inadvertently reduce the degree to which borrowers are protected from lender malfeasance. The potential for this type of opportunistic theft has increased as MFIs have moved away from joint-liability lending methodologies that required some level of group or community involvement in monitoring and collection. In the face of increasing competition, multiple borrowing, and over-indebtedness, many MFIs have systematically begun to accept (and, indeed, require) collateral of various types, which they will collect themselves, extra-judicially, in case of default. In some countries, a large proportion of microfinance loans are now made against household chattels including furniture and livestock, deposits of money with the institution (often called "forced" or

\footnotetext{
${ }^{14}$ Cull et al. (2011).

${ }^{15}$ For example, some policymakers have recommended that "forced" or "compulsory" savings, which I discuss below, be held in a trust or escrow account to protect them in case the MFI fails (CGAP 2012, p. 18.) If such a step had been fully implemented for all lenders, then it would likely have prevented the Ugandan crisis. Yet, the Ugandan government lacked the staff and capacity to enforce such a measure across the industry: implementing such a regulation without adequate supervision, or with unpredictable and irregular supervision, might have left borrowers even more vulnerable to fraud as they assumed that their money was protected not only by the benevolent intentions of the MFIs but also by government regulations.

${ }^{16}$ See Duggan (forthcoming) for an extensive and more general discussion of this problem of lender opportunism.
} 
"compulsory" savings), or the property of guarantors willing to co-sign the loan. These innovations, which help benevolent lenders efficiently recoup their money after a default, can be used by malicious lenders to steal from clients in good standing - or even from individuals to whom they have not yet given a loan.

Under other circumstances, such as with informal moneylenders, one would expect borrowers to take precautions to avoid this type of abuse. They might attempt to protect themselves by borrowing from lenders whom they knew (or knew about) or with whom they had a social or familial relationship. Without these protections, we would expect them to try to avoid borrowing as much as possible.

Yet, microfinance's stellar international reputation creates a halo effect that extends to anyone doing business under the umbrella term. Not only are borrowers more likely to make themselves vulnerable to "MFIs" in general, but it is difficult for them to differentiate between benevolent and malicious microfinance providers. Among other things, the sector's focus on outreach and inclusion means that both types of lenders often target individuals who have never borrowed in the past - and both are likely to be relatively aggressive in their sales pitches. As long as borrowers cannot reliably make these distinctions, stories of malfeasance by "microfinance" institutions may lead to a general punishment of the entire sector, as would-be borrowers avoid MFIs and governments enact onerous regulations.

This argument depends upon the idea that borrowers will treat MFIs as a group, rewarding and punishing them together, rather than as individual institutions with distinct reputations. There are, indeed, several reasons to imagine that borrowers might conceive of these institutions as a group. While large, internationally famous microfinance organizations have operated continuously - and under the same namein some areas for years and decades, in markets like Uganda this longevity is the exception rather than the rule. Since new institutions, and, obviously, malicious institutions, are particularly interested in associating themselves with the broader sector's excellent reputation, borrowers in the most chaotic areas of the sector are among the most likely to see institutions emphasize this sectoral reputation. The media have, moreover, tended to consistently and frequently emphasize the term "microfinance," even when reporting on a single institution. Finally, policymakers and others have emphasized the unity of the microfinance movement, making efforts to incorporate a larger and more diverse group of institutions under the microfinance banner rather than stressing the individuality of the MFIs themselves.

Even if borrowers and the media did try to distinguish between benevolent MFIs and malicious ones, reputation alone would not necessarily mitigate this type of opportunism. As long as either borrowers or lenders can behave opportunistically, either can lie about what has happened, and both are likely to claim that the other has cheated them. Thus it is very difficult for third party observers to differentiate between real claims of malfeasance and false ones. People may discount the claims of borrowers who say they were abused, imagining that they are trying to get out of paying debts. Institutions accused of malfeasance may successfully rehabilitate their reputations by claiming that the problems were the result of innocent errors or single instances of fraud by individual officers (now fired). These institutions may, moreover, argue that erroneous claims are being made by competitors trying to undermine their position in the market. Without some systematic means of assembling or adjudicating these claims, it is very difficult for gossip networks of uneducated borrowers - and even for media and government 
officials - to determine which claims are true and which are false. Even if microfinance's general reputation has broad implications for the market, MFIs may not be able to rely on their individual reputations to differentiate themselves from malicious lenders.

If malfeasance among institutions operating under the microfinance banner is, indeed, a serious problem, then why has it largely evaded the notice of scholars and policymakers? Part of the reason is, again, definitional. As long as one's definition of an MFI incorporates benevolent goals, then it is tempting to dismiss malicious institutions as, simply, abusive moneylenders or con artists who should not be lumped together with genuine MFIs. While this perspective has theoretical merit, if it does not reflect the way that borrowers understand which institutions are and are not "genuine" MFIs, then the gap between theory and practice may create a key threat to the sector.

Scholars have also tended to overlook these issues, in part, because of a serious selection bias in the available quantitative data on microfinance. A strong preference for large-scale quantitative analysis has painted a somewhat misleading picture of the industry: scholars have tended to gravitate toward professionally run institutions that are willing to allow researchers to observe their activities or to provide large-scale quantitative data. ${ }^{17}$ Some work has been done detailing the differences between and potential biases within these major databases. ${ }^{18}$ There are, moreover, often enormous gaps between the number of institutions in these databases and the number of institutions in operation in many countries, and both these gaps and their implications remain under-examined. For example, at the beginning of 2015, Bangladesh's MIX profile listed about 80 providers, while the country's Microfinance Regulatory Authority listed nearly 700 currently licensed MFIs. ${ }^{19}$ Uganda's MIX profile listed 33 MFIs in 2015; the most recent (2010) government census found 2257 MFIs. ${ }^{20}$ This bias has significant effects: since much of what scholars believe about microfinance is drawn from the systematic analysis of relatively high-quality data, it is both tempting and dangerous to extrapolate this picture to the entire industry without considering the selection biases associated with the available data.

Microfinance in Uganda provides a particularly good case in which to explore these issues of opportunism and reputation among MFIs. Unlike countries with strong state institutions that can mitigate lender malfeasance, including much of Latin America, Uganda has a court system beset by delays, a police force that has been widely accused of corruption, and regulatory agencies with extremely inadequate resources. The government's encouragement of microfinance and laissez faire approach to microfinance regulation and supervision, moreover, has created one of the most competitive and innovative sectors in sub-Saharan Africa.

\footnotetext{
${ }^{17}$ Databases such as the Consultative Group to Assist the Poor's MIXmarket project: www.mixmarket.org and the Microcredit Summit Campaign make much of these data publically available. See Cull et al. (2009b) for an overview of these data.

${ }^{18}$ See Bauchet and Morduch (2010) for a discussion of the differences in these datasets. Even here, Bauchet and Morduch look at data on only 2072 institutions; a fraction of the total "MFIs" in operation around the world.

${ }^{19}$ Compare http://www.mixmarket.org/mfi/country/Bangladesh (accessed February 2015) and http://www. mra.gov.bd/images/Licensed_NGO_MFIs/licenced\%20mfis-697\%20english\%20list\%20as\%20on\%2031.01. 2015.xls.pdf (accessed February 2015).

${ }^{20}$ Compare Ministry of Finance (2010) and http://www.mixmarket.org/mfi/country/Uganda, accessed October 2014.
} 


\section{Theft and Abuse in Uganda's Microfinance Markets}

Uganda takes a tiered approach to the regulation and supervision of its financial institutions (Table 1). Banks and credit institutions such as housing lenders, which are highly regulated and supervised by the Bank of Uganda, occupy the first two tiers. The third tier, composed of so-called Micro Deposit-taking Institutions (MDIs), was created by a 2003 act designed to allow the largest microfinance institutions to submit themselves to full supervision in exchange for the ability to accept and on-lend deposits from the general public. Despite much enthusiasm for the act, which many thought would create a large supervised microfinance sector, few MFIs proved interested in undergoing the transformation necessary to change tiers; by 2005, only four had completed the process, at an average cost of one million dollars per institution. ${ }^{21}$ The 2003 Act, noted the Assistant Commissioner in charge of microfinance in the Ministry of Finance, "didn't work out as expected."22

The fourth tier of the framework is a residual category that includes all other forms of lenders, including all MFIs that did not transform into MDIs. Tier 4 lenders are formally beyond supervision by the Bank of Uganda-and are, for all intents and purposes, beyond any effective government regulation. Leaving tier 4 institutions unregulated was an intentional effort by the government only "to regulate what it could supervise" and to "avoid overly burdensome regulations" that might have a chilling effect on the growth of the microfinance sector. ${ }^{23}$ Although tier 4 institutions are formally required to register with the government, they can do so as moneylenders, companies, NGOs, or savings and credit cooperatives (SACCOs), each falling under a different regulatory purview. In practice, virtually anyone can become a "microfinance institution."

The government's efforts to promote unbridled entry and competition were extremely effective. In 2001, some analysts estimated that Uganda had the most competitive microfinance sector in Africa; by 2006, nearly three quarters of all of the microfinance institutions in the country said that they were in direct competition with at least one other institution. ${ }^{24}$ In the same year, a census of MFIs suggested that there were just over 800 institutions and 1200 outlets (including branches) providing small loans, most of them clustered in urban and peri-urban areas. ${ }^{25}$

The first ever census of Ugandan MFIs, done in 2006, illustrated how little the government knew about the sector and how frequently MFIs were entering and exiting the market. While initial estimates based on registration figures suggested that 3360 tier 4 MFIs were active in the country, census agents crisscrossing the country with global positioning devices found that only 779

\footnotetext{
${ }^{21}$ Bagyenda (2011), p. 133. By 2010 the number of MDIs had dropped to three, after one of the original four became a Tier 1 bank.

${ }^{22}$ Author interview with Henry P. Mbaguta, Ag. Commissioner, Ministry of Finance, Planning \& Economic Development, Uganda, Kampala, June 17, 2014.

${ }^{23}$ Bagyenda (2011), p. 126.

${ }^{24}$ Aggrey Rainherojon, "Largest Number of MFIs in Africa," The Monitor (Uganda), November 30, 2001. 2006 figure calculated from Ministry of Finance (2006).

${ }^{25}$ Ministry of Finance (2006).
} 
Table 1 Financial institutions by regulatory tier ${ }^{\mathrm{a}}$

\begin{tabular}{|c|c|c|c|c|c|}
\hline \multirow[t]{2}{*}{ Tier } & \multirow[t]{2}{*}{ Type of institution } & \multirow{2}{*}{$\begin{array}{l}\text { Start-up capital } \\
\text { requirement? }\end{array}$} & \multirow[t]{2}{*}{ Deposit mobilization? } & \multicolumn{2}{|c|}{ Number of institutions } \\
\hline & & & & 2005 & 2010 \\
\hline & \multicolumn{5}{|c|}{ Subject to Bank of Uganda supervision } \\
\hline 1 & Commercial banks & Yes & Yes & 15 & 23 \\
\hline 2 & Credit institutions ${ }^{\mathrm{b}}$ & Yes & Yes & 7 & 3 \\
\hline 3 & $\begin{array}{l}\text { Micro-deposit-taking } \\
\text { institutions (MDIs) }\end{array}$ & Yes & Yes & 4 & 3 \\
\hline & Not subject to supervi & & & & \\
\hline \multirow[t]{5}{*}{4} & $\begin{array}{l}\text { Savings and credit } \\
\text { cooperatives } \\
\text { (SACCOs) }\end{array}$ & No & $\mathrm{No}^{\mathrm{c}}$ & 628 & 2065 \\
\hline & Moneylenders & No & No & ] & 53 \\
\hline & Companies & No & No & \multirow{2}{*}{151} & 49 \\
\hline & NGOs and others ${ }^{\mathrm{d}}$ & No & No & & 83 \\
\hline & Total Tier 4 & & & 779 & 2250 \\
\hline
\end{tabular}

\footnotetext{
${ }^{a}$ Tier 4 figures from Friends Consult (2007) and Ministry of Finance (2010); Ministry of Finance (2006) lists 792 tier 4 MFIs. Figures for commercial banks, credit institutions and MDIs from Bank of Uganda (2005) and Bank of Uganda (2010).

${ }^{\mathrm{b}}$ Including Housing Finance Companies and other formal credit institutions

${ }^{c}$ SACCOs may collect savings from members and lend it to other members

d "Other" or "Not stated" in the Government of Uganda 2010 Census of Microfinance Institutions. (Ministry of Finance: 2010)
}

of these institutions were, in fact, operating. The gap between the number of registered institutions and those actually in operation was particularly dramatic in the case of savings and credit cooperatives (SACCOs): nearly half of the 1274 institutions with current registrations were no longer operating; of the ones that were operating, nearly $20 \%$ had been open for 1 year or less. ${ }^{26}$ A similar census conducted in 2010 showed that $60 \%$ of all active institutions in the country had opened in the previous 4 years. $^{27}$

In 2006, the modal MFI in Uganda was small, locally run, and operated by a relatively inexperienced Ugandan staff. Most had four or fewer employees and were making fewer than 100 loans per year. ${ }^{28}$ Nearly two thirds of the directors of these institutions had fewer than 5 years of experience in microfinance, and almost a quarter reported that they had only a secondary school education (or less) - a figure that had hardly changed in $2010 .{ }^{29}$ More than $90 \%$ of loan officers reported that they had worked in the industry for less than a year. The vast majority of these institutions kept

\footnotetext{
${ }^{26}$ Ministry of Finance (2006), Friends Consult (2007).

${ }^{27}$ Ministry of Finance (2010), Figure 2.2.

28 84\% operated out of a single branch; $75 \%$ had four or fewer employees. Ministry of Finance (2006).

${ }^{29}$ In 2010, $24 \%$ of MFI managers had no education beyond secondary school. Ministry of Finance (2010).
} 
their accounts by hand; three quarters had their accounts audited by their directors or not at all; and $16 \%$ of all of the registered MFIs in the country did business out of the director's house. ${ }^{30}$ In contrast to the high repayment rates associated with international microfinance institutions, delinquency rates among these local institutions were high: tier 4 institutions reported that they had made 354,000 loans in 2005, of which 273,000 (77\%) were outstanding. ${ }^{31}$

Multiple borrowing became a serious problem, and Ugandan MFIs sought new ways to protect themselves from default. ${ }^{32}$ Many abandoned or minimized group-based lending, focusing instead on making loans to individuals secured on chattel, money, and titled property. Individual loans began to dominate: by 2006, nearly all MFIs in Uganda offered individual loans, and more than a third relied exclusively on this model. ${ }^{33}$ In the same year, about $85 \%$ of clients borrowing from MFIs reported that they had individual loans. ${ }^{34}$

The practice of using money as collateral created a number of opportunities for malfeasance. Deposits taken as collateral were not regulated by the Bank of Uganda as long as they did not bear interest and were not used to make loans. These deposits typically came in the form of forced savings, requiring the borrower to deposit a percentage of the principal with the institution before receiving the loan. If the borrower failed to repay, then the institution would reimburse itself from these deposited funds; if he repaid as agreed, then he would be free to withdraw the money. By 2003, more than $80 \%$ of borrowers reported that they had been required to make such a deposit to secure a loan, and nearly two thirds of MFIs reported that they collateralized loans on this type of savings. ${ }^{35}$

\section{Fraud and Theft by Ugandan MFIs}

These lending models allowed organizations operating as microfinance institutions to engage in frank fraud and theft, taking advantage of the fluidity of the microfinance sector and the pervasive practice of requiring forced savings to steal from borrowers before disappearing. In some cases, institutions operating as MFIs stole money from borrowers without making any loans. The prevalence of this type of fraud underscores the ways that microfinance enables opportunism by lenders, while the government's difficulties in mitigating these problems demonstrate some of the unique challenges associated with regulating a sector that is so strongly associated with benevolent ambitions.

One example of this type of fraud involved an MFI named Caring for Orphans, Widows, and the Elderly (COWE). This organization initially appeared to be an unremarkable NGO working in microfinance and health insurance for vulnerable

\footnotetext{
${ }^{30}$ Ministry of Finance (2006).

${ }^{31}$ This calculation is difficult as the relationship between disbursed loans and outstanding loans is vague. Since few of these loans are likely to be for much more than 12 months, however, we can draw at least some conclusions about the magnitude of delinquencies. For comparison, the regulated MFIs reported $32 \%$ of their loans outstanding. Ministry of Finance (2006).

32 See McIntosh et al. (2005) on the inverse relationship between competition and repayment rates in Uganda.

${ }^{33}$ Ministry of Finance (2006).

${ }^{34}$ Calculated from data in FinScope Uganda (2007).

35 Wright and Rippey (2003).
} 
populations in several areas of rural Uganda. Its model seemed quite standard: individuals paid a membership fee, a fee to enroll in the healthcare program, and a forced savings deposit into a collateral account held by the institution, in anticipation of receiving a loan. COWE duly registered with the NGO Registration Board of the Ministry of Internal Affairs in 2001, and its employees worked through local officials and community leaders in each of the areas where it had offices. By 2002, local papers were noting that the organization would provide microfinance loans that "will enable the beneficiaries to engage in productive work and reduce poverty." 36

In April 2002, there were widespread allegations that COWE's directors had been engaged in fraud. The institution was accused of failing to provide services as promised and illegally seizing its members' deposits, and four executives of the organization were accused of embezzling more than 200 million Uganda shillings (approximately $\$ 100,000)$, largely from impoverished borrowers. ${ }^{37}$ Investigations revealed that COWE was operating in 15 districts, even though it was only licensed to operate in three. The Ugandan NGO board froze the bank accounts of the organization's directors and suspended its license. Yet, the COWE directors protested that the NGO board had acted without a hearing, and that the board had based its action on slanderous and vengeful allegations leveled by competing microfinance institutions and a former director who had been refused a large loan. ${ }^{38}$ COWE won re-registration in a High Court appeal. ${ }^{39}$

Less than 6 months after COWE was allowed to resume its operations, newspapers once again began to report complaints of fraud. COWE members in several parts of the country complained that the organization had shut its doors and taken their deposits without ever giving them loans. Officials estimated that more than five billion Ugandan shillings ( $\$ 2.7$ million) was lost across the country, with more than 700 million shillings (approximately \$390,000) taken from widows and orphans in a single district. ${ }^{40} \mathrm{~A}$ local paper quoted a 75-year-old widow who complained that the COWE directors should "either kill us or they bring back our money. I sold all my six pigs and gave the money to the officials of COWE who promised to give me a big loan and free medical service but I have got nothing since. They have closed all their offices."

Despite these well-publicized allegations, COWE continued to operate-and defraud clients-for years. In 2007, 5 years after the organization had first had its registration suspended and reinstated, COWE was accused of having defrauded a new tranche of borrowers across the country. As these new allegations came to light, the Minister for Internal Affairs noted that "if organizations are registered as NGOs, it is very difficult to pursue them." but the organization had simply re-registered as a different type of tier 4 lender with no problem.

\footnotetext{
36 Jonathan Angura, "COWE helps orphans, elderly," The New Vision (Uganda), March 31, 2002.

37 “COWE Officials' Accounts Frozen," The New Vision (Uganda), July 12, 2002.

38 John Odyek and Wilsons Manyire, "COWE Operations Illegal - NGO Board," The New Vision (Uganda), May 15, 2002; "COWE woes," The New Vision (Uganda), July 31, 2002.

39 "IN BRIEF: COWE case," The New Vision (Uganda), September 9, 2002.

${ }^{40}$ Darious Magara, "NGOs closed over fleecing residents," The New Vision (Uganda), March 17, 2007.

${ }^{41}$ S. Onyait "COWE came to Tororo and went away!" Letter, The New Vision (Uganda), October 21, 2003; Abraham Odeke "Tororo residents conned of sh300m, petition government," The New Vision (Uganda), November 25, 2003.

42 Joyce Namutebi and Catherine Bekunda, "MPs want action on cheating NGOs," The New Vision (Uganda), November 20, 2008.
} 
The media may be partly to blame for the fact that individuals failed to avoid COWE, even after it had received so much bad press. As late as 2007, the largest newspaper in the country (which had previously covered the various allegations against the organization in great detail), described the organization as "a charity that supports orphans and the elderly" without additional comment. ${ }^{43}$ Even in 2008-after the directors of the organization had finally been arrested and the President had called for them to be punished - the same paper reported the organization's involvement in an unrelated lawsuit by describing COWE as an "NGO, which cares for orphans and widows," making no mention of any of the allegations or charges against it. ${ }^{44}$

In a 2014 interview, the Director of the Bank of Uganda's Non-Bank Financial Institutions Department was confident that some of the people who had been involved in COWE were continuing to defraud vulnerable borrowers. ${ }^{45}$ He noted, ruefully, that his department had no authority to supervise or investigate tier 4 lenders such as COWE, but could only enforce restrictions such as forcing unregulated organizations to stop using the word "bank" in their names. When victims of fraud wrote letters of complaint to the Bank of Uganda, he explained, his office was forced to advise them to seek remedy in the courts.

\section{Crisis in Ugandan Microfinance}

Although COWE was the most remarkable case of widespread theft, it was far from the only one that received attention. In 2007, COWE and several other tier 4 MFIsincluding Dutch International, and Together Everybody Achieves More (TEAM) were accused of embezzling more than 11 billion shillings (approximately \$6 million) from clients, much of it deposits associated with loans. ${ }^{46}$ As public fear and anger reached a fever pitch, the Bank of Uganda issued a statement cautioning borrowers to avoid depositing money with unsupervised institutions: "BoU will not protect any person who deposits money with a person who is not licensed to take deposits or who aids and abets crime and the perpetuation of fraud in the Ugandan financial sector."47

Several months later, the police began to investigate MFIs across the country. Lending institutions with names like Development Scheme Microfinance Ltd., Support Organization of Micro Enterprises Development, Key Business Microfinance, and others were shuttered. ${ }^{48}$ Newspapers reported that institutions had given their clients "the run-around" and refused to give them access to deposits that they had a right to withdraw, while other clients complained that the institutions' records underreported their deposits. ${ }^{49}$

\footnotetext{
$\overline{43}$ Onesimus Twinamasiko, "COWE gives items worth sh40m," The New Vision (Uganda), August 12, 2007.

${ }^{44}$ Hillary Nsambu, "Court clears ex-MP Kafiire," The New Vision (Uganda), January 24, 2008.

${ }^{45}$ Author interview with Charles Owiny Okello, Director, Non Bank Financial Institutions Department, Bank of Uganda, Kampala, Uganda, June 16, 2014.

${ }^{46}$ Some of the embezzled money was deposited with these institutions as voluntary savings, rather than "forced savings," though the institutions' status as MFIs undoubtedly enabled both forms of deposit-taking.

${ }^{47}$ Joseph Olanyo, "BoU Warns on MFIs," The Monitor (Uganda), January 11, 2007.

${ }^{48}$ James Abola, "Microfinance Bodies Should Be Watched Closely," Opinion, The Monitor (Uganda), September 29, 2007; Michael Ssali, "Masaka Police Close Microfinance Institution," The Monitor (Uganda), October 22, 2007; Martin Ssebuyira, "Key Microfinance Customers Bitter Over Cash Hold Up," The Monitor (Uganda), November 7, 2007.

49 Abola, "Microfinance Bodies."
} 
Panic precipitated mob actions against a number of lending institutions. In Kampala, as many as 800 clients attacked a large MFI, forcing the police to intervene and provide an armed escort for the institution's staff. "We want our money back," one member of the crowd said: "these people keep on tossing us by shifting the dates when we are to get our money, but even Bank of Uganda passed a statement saying the unlicensed institutions were not recognized by them, so it means we can't get our money back." ${ }^{50}$ Rumors that the MFI was under investigation by the police were dismissed by the lender's Chief Executive Officer as being "just" the result "of our competitors" malice." 51

The Bank of Uganda responded to the crisis by reiterating its advice to use only supervised institutions. A local paper pointed out that the Bank's response "effectively implies that the hundreds of MFIs that operate throughout the country can literally disappear with depositors' money with little worry of punitive action from anyone."52 Many observers complained that the Bank's actions were insufficient. Under the headline "Quack MFIs May Throw Economy Into Chaos," the main independent newspaper editorialized that the central bank "should have gone beyond mere warning and directed for closure of unlicensed microfinance institutions." 53

While the immediate crisis subsided, the general issues of fraud did not. Papers carried reports of new pyramid schemes masquerading as MFIs, asking "how could so many people be duped so quickly?" and noting that one had "won the public over by marking itself as a non-profit making, philanthropic organization 'designed to assist marginalized and disadvantaged groups in society." "54 Another lender opened under the name Visa Finance, using radio advertisements to attract clients who were required to pay a number of application fees and deposit $25 \%$ of the value of the loan for which they were applying. The proprietors of this institution absconded in the middle of the night; a police investigation was obstructed by the fact that they had used only their first names on official documents and had turned off the only cell phone they provided as a contact. ${ }^{55}$ Several MFIs were closed for fraud in 2009, including one whose regional offices continued to operate for more than a month after its Kampala office had been shuttered. $^{56}$

Both logistics and politics contributed to this supervisory failure. The Bank of Uganda was not authorized to supervise or regulate microfinance institutions, and local officials and police did not systematically ensure that unregulated MFIs were not breaking the law. Fraud was, as a result, often uncovered only when large numbers of borrowers began to complain to local media - and, even then, little seems to have

\footnotetext{
${ }^{50}$ Richard Wanambwa and Joseph Miti, "Angry Customers Mob Front Page Micro Finance," The Monitor (Uganda), December 4, 2007.

51 Stephen Wandera, "Front Page Management Dismisses Closure Claims," The Monitor (Uganda), October 3, 2007.

52 Elias Biryabarema and Walter Wafula, "Deposit cash in micro-finance at own risk - BOU," The Monitor (Uganda), November 28, 2007.

53 "Quack MFIs May Throw Economy Into Chaos," (Editorial), The Monitor (Uganda), January 3, 2008.

54 Solomon Muyita and Pauline Kairu, "Shs Two Billion Jinja Deposit Scam Heralds Return of Gift Circles." The Monitor (Uganda), September 25, 2008.

55 John Augustine Emojong, "Malaba Conmen Leave Locals Crying to the Bank," The Monitor (Uganda), July 23, 2009.

56 Andrew Bagala, "Police Close Three Microfinance Firms," The Monitor (Uganda), September 11, 2009.
} 
been done in most cases. Efforts to stem fraud were also complicated by the concurrent expansion of a government lending program administered through SACCOs. New institutions sprang up to take advantage of this money, and the number of SACCOs in the country trebled in 4 years. ${ }^{57}$ These institutions continued to be wholly unregulated even while operating under this government umbrella; complaints of fraud persisted, and newspapers periodically printed stories about the arrest of SACCO directors. ${ }^{58}$

The government had long been working on legislation that would bring all tier 4 MFIs under regulation. Prior to 2008, legislators had imagined that the new law would be SACCO-specific; after the crisis, however, they realized that this type of targeted regulation would be "inadequate," since it would leave NGOs, moneylenders, and others outside of the regulated sphere. ${ }^{59}$ By 2014, it was proposing a combination of regulatory authorities that would manage the prudential and non-prudential regulation of the entire sector, using access to lending from a development fund as an incentive to submit to regulation. Yet supervising - and even designing regulation for-tier 4 institutions is, as one government official put it, "an enormous task." ${ }^{60}$ Indeed, at the beginning of 2015, nearly 7 years after the government announced that it was at work on the measure, the bill had still not been presented to the legislature.

\section{Self-Exclusion by Borrowers in the Aftermath of the Crisis}

It is impossible to know how much money has been stolen as a result of fraud by Ugandan MFIs or by how many institutions. There are no systematic data on thefts, complaints, or closures, and the newspaper and police reports that exist are closely associated with moments of widespread panic. The number of people directly affected may well not have been large: in 2009, fewer than one percent of survey respondents reported that they had lost money to theft or fraud by an outside party or committee member of a financial institution. ${ }^{61}$ In $2013,10 \%$ of respondents responded affirmatively to the question: "Have you ever been dissatisfied with a financial service provider (e.g., because you were treated unfairly, you lost your money)?"62 While it is impossible, from this question, to know how many people lost money and how many felt unfairly treated or otherwise dissatisfied, the overall proportion of dissatisfied clients remains small.

Yet simple calculations of the amounts of money lost may fail to capture broader losses of trust in the financial sector as a whole. By this standard - the erosion of trust in financial institutions - malfeasance by unregulated microfinance institutions may have contributed to a remarkable negative shift in public perception of the sector. In 2006, before malfeasance in the microfinance industry had come to light, $57 \%$ of survey respondents agreed with the statement "I trust formal commercial banks," and $45 \%$ reported that they trusted SACCOs (Fig. 1). Seven years later, in 2013, more than three quarters of respondents said that they did not trust commercial banks, and more than $80 \%$ reported that they distrusted SACCOs. In just 4 years, between 2009 and

\footnotetext{
${ }^{57}$ Ministry of Finance (2010).

${ }^{58}$ Peter Nyanzi, "EU Delegation Chief Calls for SACCOs Law," The Monitor (Uganda), January 28, 2008.

${ }^{59}$ Mbaguta interview (2014).

${ }^{60}$ Mbaguta interview (2014).

${ }^{61}$ Calculated from Finscope (2010), question D10.1 and D10.2.

${ }^{62}$ Calcuated from Finscope (2013), question N1.9.
} 


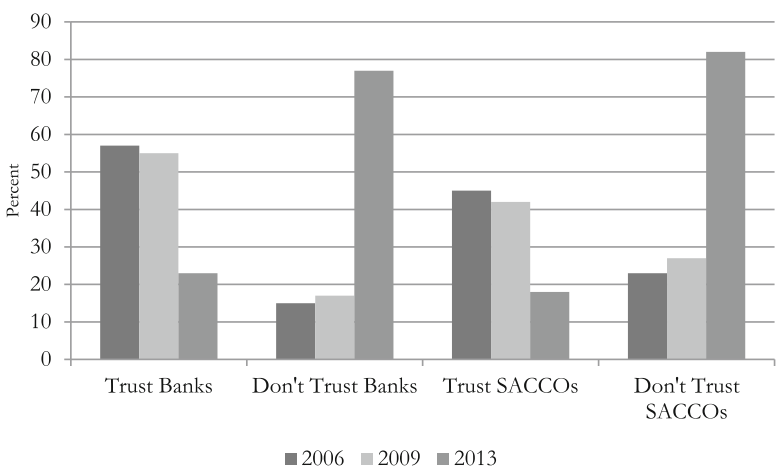

Fig. 1 Trust in Banks and SACCOs, 2006-2013 (calculated from Finscope (2007; 2010; 2013))

2013, the number of people reporting that they trusted commercial banks declined from more than $50 \%$ to less than $25 \%$. $^{63}$

In fact, in 2013 Ugandans reported comparatively low levels of trust in all types of financial institutions (Fig. 2). It is, perhaps, not surprising that Ugandans might be distrustful of MFIs, moneylenders, and SACCOs in light of the pervasive - and wellpublicized - misdeeds within this essentially unregulated portion of the lending sector. Indeed, the Bank of Uganda's statements during the crisis were designed to buttress trust in regulated institutions and direct borrowers away from unregulated ones. Yet, respondents report an overwhelming distrust of every single category of financial institution, including commercial banks and micro-deposit-taking institutions (MDIs), both of which are well-regulated and well-supervised. If malfeasance in the microfinance sector did, indeed, contribute to these remarkable changes in public opinion, then it may be that trust in Uganda's entire financial sector has suffered from the exploits of a relatively small number of con artists.

One must be somewhat cautious in this interpretation: among other things, there is a lag between the most serious reports of malfeasance and the largest change in public opinion. While there is relatively little change in trust for financial institutions between 2006 and 2009, which spanned the height of the microfinance crisis in Uganda, there is a substantial shift between 2009 and 2013. Yet, such a lag might be explained by the fact that Ugandans - and, particularly, the poor and illiterate - rely heavily on word-ofmouth (rather than newspaper or radio reports) in assessing financial institutions. ${ }^{64}$ It is not implausible that it could take a year or more after such a crisis for word to spread and Ugandans to render judgment.

Moreover, the pattern of the change does not provide compelling support for several plausible alternate explanations. For example, it is possible that the global financial crisis, which occurred during roughly the same period as the Ugandan microfinance crisis, precipitated a diminution of trust in banks around the world. One could also imagine that tightened credit as a result of the global crisis might have led to a loss of confidence in local institutions. Yet, in either case one would not expect all categories of financial institution to suffer the same loss of trust. If the shift was the result of the

\footnotetext{
${ }^{63}$ This is not a longitudinal survey, so this shift does not show a change in perception among the same group of respondents. The surveys from all 3 years were, however, done by the same organization and designed to capture the perceptions of the same broadly representative population.

${ }^{64}$ Finscope (2007).
} 


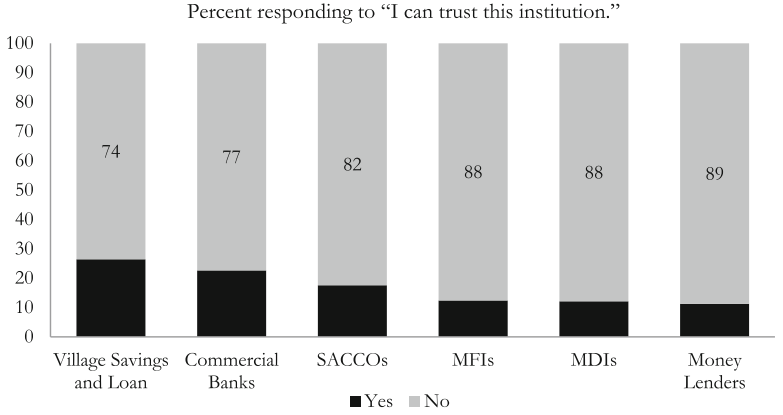

Fig. 2 Trust in lending institutions, 2013 (calculated from Finscope (2013))

actions of financial institutions in the USA and elsewhere, then we might expect Ugandans to increase (or, at least, not lose) their levels of trust in indigenous institutions like MDIs and village savings and loans. In addition, the Ugandan government was lending extensively through SACCOs during this period. Thus, if credit restrictions or interest rates were driving the change, then we might expect to see SACCOs suffer much less than other institutions - and, perhaps, even enjoy a reputational benefit from their access to government capital. Finally, Uganda's financial sector, which saw a series of bank failures in the late 1990s and early 2000s, weathered the global financial crisis quite well. Indeed, a review of Ugandan newspapers during this period suggests few explanations for this shift in trust apart from the malfeasance and dysfunction in the microfinance sector. Rather, local news highlights the degree to which observers and reporters continue to return to examples of malfeasance of the microfinance crisis, both in the immediate wake of the crisis and in more recent reporting about the sector. ${ }^{65}$

This shift is not limited to reports of trust in financial institutions: Ugandans also appear to have changed their borrowing behavior. Between 2006 and 2009, the proportion of survey respondents reporting loans from "informal" lenders, a category that here included all MFIs except SACCOs, increased from 25 to $32 \%{ }^{66}$ Yet, in the following 4 years, that percentage decreased to only $18 \%$-lower than it had been 7 years earlier (Fig. 3). This change does not primarily reflect a shift toward borrowing from other sources: while slightly more respondents reported borrowing from banks and cooperatives between 2009 and 2013, the largest shift is an increase in the number of respondents who report that they are not borrowing from any source - those who were "excluded" from borrowing. Indeed, after a marked reduction in 2009, by 2013 the number of excluded respondents had returned to essentially its 2006 level. Ugandans were not only declining to take loans from informal sources including MFIs, but many were not borrowing at all. Whether or not this trend away from informal finance and toward exclusion is attributable to the microfinance crisis, it is certainly not one that proponents of microfinance hoped to produce.

In recent years, Ugandan MFIs have moved away from forced savings and toward other forms of collateral. In 2003, $80 \%$ of borrowers reported that they had been required to make a forced savings deposit to get a loan; 10 years later, a minority of

\footnotetext{
${ }^{65}$ For example: "Stop Failing SACCOs-Minister Warns Politicians," The New Vision (Uganda), June 27, 2013; "SACCO employees flee with Sh 1.9 Billion," The New Vision, September 19, 2012; and "Lack of Law Hinders SACCOs Growth," The New Vision (Uganda), December 31, 2010.

${ }^{66}$ Finscope (2013).
} 
Percent of Survey Respondents Borrowing From:

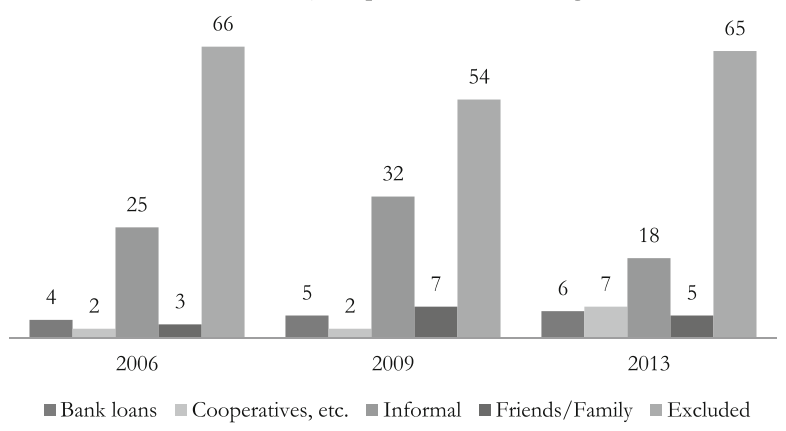

Fig. 3 Self-reported borrowing, 2006-2013 (calculated from Finscope (2007; 2010; 2013))

borrowers reported that they had taken loans secured against anything other than titled land, chattel, or livestock (Table 2). ${ }^{67}$ Non-SACCO MFIs were the least likely to rely on this "other," intangible security, including forced savings, salary assignment, group lending, or other forms of guarantee. Although this shift is not surprising, given the trend away from group liability and the crisis associated with forced savings, it threatens to undermine many of the goals of the microfinance movement. If one is interested in expanding access to credit, then the fact that nearly $50 \%$ of non-SACCO microfinance loans are secured against some form of land title is disheartening. Uganda's microfinance market appears to be becoming more exclusionary across several dimensions.

Finally, attitudes toward borrowing among the general public underscore the problematic state of Uganda's lending sector. In 2013, $79 \%$ of survey respondents agreed with the statement "I often think that I would like to start my own business, but I can't get enough money"-making them, presumably, potential candidates for microfinance loans. Yet, among the group who agreed with that statement, $61 \%$ also agreed with the statement that "Borrowing is a risky business," and $69 \%$ agreed that "I try to avoid taking loans as much as possible." 68 Nearly all of those who said they could not get enough money to start their own businesses agreed with both other statements. More than a decade after Uganda was hailed as having one of the most competitive and least onerously regulated microfinance sectors in Africa, some of the very people who seem most likely to be candidates for microfinance loans appear to be avoiding them. After many years of empowering lenders in an effort to mitigate problems of credit rationing, a key challenge for Ugandan microfinance may now be to empower borrowers to overcome their avoidance of borrowing.

\section{Conclusions and Implications}

In this paper I have shown that key microfinance lending methodologies not only put borrowers at risk, but also that unscrupulous lenders have taken advantage of essentially unregulated microfinance markets to steal from clients. The implications of this opportunistic behavior, I argued, extend beyond the specific harm to the borrowers who lost money

\footnotetext{
${ }^{67}$ Wright and Rippey (2003), and Finscope (2013).

${ }^{68}$ Calculated from Finscope (2013). Combining "Strongly Agree" and "Agree" responses. Emphasis added.
} 
Table 2 Percent of borrowers reporting that they were required to provide each form of collateral, by institution type, $2013^{\mathrm{a}}$

\begin{tabular}{llll}
\hline & Land title & Chattel and livestock & Other \\
\hline Bank & $30 \%$ & $18 \%$ & $47 \%$ \\
MDI & $28 \%$ & $36 \%$ & $35 \%$ \\
Other MFIs & $47 \%$ & $21 \%$ & $32 \%$ \\
SACCOs & $29 \%$ & $18 \%$ & $41 \%$ \\
Moneylender & $24 \%$ & $18 \%$ & $41 \%$
\end{tabular}

${ }^{a}$ Calculated from Finscope (2013)

and property. Insofar as these abuses have tarnished the microfinance sector as a whole in Uganda, borrowers who could benefit from loans may be avoiding microfinance altogether.

Uganda's experience with this type of lender opportunism is far from unique. Borrowers in several other countries have suffered similar problems with illicit collection by "microfinance" institutions. In Bangladesh, the "unauthorized repossession of assets, including the very roofs off of recipients' houses," is "not infrequent." have lost money in pyramid schemes calling themselves banks. ${ }^{70}$ In China, rotating savings and credit groups have failed as both members and group leaders have absconded with savings. ${ }^{71}$ The South African government has explicitly prohibited MFIs from collecting forms of collateral, like ATM cards, that make it easy for lenders to steal from borrowers outright or to charge fees and penalties that were not outlined in the loan contract.

The alternative perspective on the risks of microfinance presented in this paper suggests new directions for the regulation of the sector. The notion that borrowers are vulnerable to opportunistic lenders requires a reevaluation of policies such as the legality of unsupervised collection and the use of deposits as collateral. Insofar as either borrowers or lenders can behave opportunistically and institutions such as courts protect both borrowers and lenders, then policies that allow lenders to circumvent these institutions and collect property from borrowers on their own are not necessarily the best alternative to slow and corrupt adjudication.

While traditional regulation and supervision may be logistically prohibitive in these markets, the peer pressure long associated with borrower monitoring in microfinance offers a potential solution. Where microfinance models currently emphasize using joint liability and social pressure to prevent opportunism by borrowers, similar strategies may allow MFIs to punish fellow lenders who behave badly-or, at least, to help borrowers identify and avoid malicious lenders. By creating incentives for lenders to identify, screen, monitor, and punish one another, this type of regulatory innovation may be able to harness the interests of benevolent MFIs to keep con artists out of the sector. At the very least, it may be able to give borrowers a way to distinguish between genuinely benevolent lenders and those who are hiding malicious intentions behind microfinance's good reputation. ${ }^{72}$

\footnotetext{
$\overline{{ }^{69} \text { Cons and Paprocki (2008), p. } 2 .}$

${ }^{70}$ Emma Ujah, "NDIC warns Nigerians against wonder banks," The Vanguard (Nigeria), September 26, 2014.

${ }^{71}$ Tsai (2000).

${ }^{72}$ See Duggan (forthcoming) on the way self-regulation reduced these types of abuses in the USA and Britain in the early twentieth century.
} 
Finally, researchers and policymakers must take a more comprehensive view of what constitutes "microfinance." Definitions of microfinance that focus on lenders' motivations create an in-built selection bias in evaluations of these markets. In many places, the modal MFI bears little resemblance to the well-run and internationally known institutions that serve as the standard bearers for the global industry. These small institutions are not necessarily malicious or even poorly run. The possibility that they could be, however, along with the risks of having opportunistic lenders preying on vulnerable borrowers, suggests that laissez faire supervision coupled with broad efforts to encourage competition may be the wrong strategy for many developing credit markets. The worst institutions operating under microfinance shingles may leave vulnerable borrowers significantly poorer than they were-as well as disillusioned with the entire microfinance movement.

This paper is by no means a condemnation of the microfinance enterprise. Rather, it suggests that the next step for microfinance policy ought to be to identify the full set of risks inherent to this type of lending and to consider institutional and regulatory means of mitigating these risks. At the very least, it suggests that we ought to be more circumspect about encouraging unregulated, profit-driven lenders to systematically target some of the most vulnerable members of society-especially under the banner of a Nobel Prize-winning concept.

Open Access This article is distributed under the terms of the Creative Commons Attribution 4.0 International License (http://creativecommons.org/licenses/by/4.0/), which permits unrestricted use, distribution, and reproduction in any medium, provided you give appropriate credit to the original author(s) and the source, provide a link to the Creative Commons license, and indicate if changes were made.

\section{References}

Bagyenda J. Uganda's experience in regulating microfinance: deposit-taking institutions. In: Rushidan Islam R, Lila R, editors. Microfinance regulations for development. Dhaka: The University Press for the microcredit regulatory authority; 2011.

Bank of Uganda. The Annual Supervisory and Regulatory Report. Kampala; 2005.

Bank of Uganda. Annual Supervision Report. Kampala; 2010.

Banerjee A, Duflo E, Glennerster R, Kinnan C. The miracle of microfinance? Evidence from a randomized evaluation. Am Econ J: Appl Econ. 2015;7(1):22-53.

Bauchet J. Morduch J, Selective knowledge: reporting biases in microfinance data. Perspectives on Global Dev and Tech. 2010;9(3-4):240-269.

Brix L, McKee K. Consumer protection in low-access environments: opportunities to promote responsible finance. Consultative Group to Assist the Poor, Focus Note No. 60. 2010.

Cons J, Paprocki K. The limits of microcredit - A Bangladesh case” Backgrounder, Goldin Institute. 2008.

Consultative Group to Assist the Poor. A guide to regulation and supervision of microfinance: consensus guidelines. Washington: Consultative Group to Assist the Poor; 2012.

Cull R, Demirgüç-Kunt A, Morduch J. Microfinance tradeoffs: regulation, competition, and financing. Washington: World Bank Policy Research Working Paper 5086, World Bank; 2009a.

Cull R, Demirgüç-Kunt A, Morduch J. Microfinance Meets the Market. J Econ Perspectives 2009b;23(1): 167-192.

Cull R, Demirgüç-Kunt A, Morduch J. Does regulatory supervision curtail microfinance profitability and outreach? World Dev. 2011;39(6):949-65.

Dichter T, Harper M, editors. What's wrong with microfinance? UK: Practical Action Publication; 2007.

Duggan C. The Institutional Foundations of Lending: Indirect Regulation and State-Building. Cambridge: Cambridge University Press; forthcoming. 
Finscope Uganda. Results of a national survey on access to financial services in Uganda; Final report. Kampala; 2007.

Finscope Uganda. Results of a National Survey on Demand, usage and access to financial services in Uganda. Kampala: Steadman Now Synovate (U) Limited; 2010.

Finscope Uganda, FinMark Trust, and Economic Policy Research Centre. Finscope III survey report findings. Kampala: Economic Policy Research Centre; 2013.

Friends Consult for The Association of Microfinance Institutions of Uganda. Status of Missing SACCOs and MFIs from the 2005/2006 Census of Tier 4 Institutions. Kampala; 2007.

Ganle JK, Afriyie K, Segbefia, AY. Microcredit: empowerment and disempowerment of rural women in Ghana. World Dev. 2015;66:335-45.

Greif A. Institutions and the path of the modern economy, lessons from medieval trade. New York: Cambridge University Press; 2006.

Hoff K, Stiglitz JE. Moneylenders and bankers: price-increasing subsidies in a monopolistically competitive market. J Dev Econ. 1998;55:485-518.

Hulme D. Is microdebt good for poor people? A note on the dark side of microfinance. In: Dichter T, Harper M, editors. What's wrong with microfinance? UK: Practical Action Publication; 2007. p. 19-22.

Karim L. Microfinance and its discontents. Minneapolis: University of Minnesota Press; 2011.

Ledgerwood J, Earne J, Nelson C, editors. The new microfinance handbook. Washington: The World Bank; 2013.

Mair J, Martí I, Ventresca M. Building inclusive markets in rural Bangladesh: how intermediaries work institutional voids. Acad Manag J. 2012;55:819-50.

McIntosh C, de Janvry A, Sadoulet E. How rising competition among microfinance institutions affects incumbent lenders. Econ J. 2005;115:987-1004.

Ministry of Finance. Planning and economic development and DFID financial sector deepening project Uganda. Kampala: Report of a Census of Financial Institutions in Uganda; 2006.

Ministry of Finance, Planning and Economic Development and Uganda Bureau of Statistics. Kampala: Report on Census of Microfinance Institutions in Uganda; 2010.

Rahman A. Women and credit in rural Bangladesh. Boulder: Westview Press; 1999.

Ramusen EB. Games and information. 4th ed. Oxford: Blackwell Publishers; 2007.

Ray D. Development economics. Princeton: Princeton University Press; 1998.

Rippey P. Princes, peasants and pretenders: the past and future of African microfinance. In: Dichter T, Harper M, editors. What's wrong with microfinance? UK: Practical Action Publication; 2007. p. 109-20.

Stiglitz JE, Weiss A. Credit rationing in markets with imperfect information. Am Econ Rev. 1981;71(3): 393-410.

Tsai KS. Banquet banking: gender and rotating savings and credit associations in South China. China Q. 2000;161:142-70.

Tsai KS. Imperfect substitutes: the local political economy of informal finance and microfinance in rural China and India. World Dev. 2004;32(9):1487-507.

Van Rooyen C, Stewart R, De Wet T. The impact of microfinance in Sub-Saharan Africa: a systematic review of the evidence. World Dev. 2012;40(11):2249-62.

Wright GAM, Rippey P. The competitive environment in Uganda: implications for microfinance institutions and their clients. Uganda: MicroSave-Africa, FSDU, Imp-Act; 2003.

Wydick B. Games in economic development. New York: Cambridge University Press; 2008.

Catherine S. M. Duggan Professor of Management and Political Economy at African Leadership University (ALU) School of Business, Rwanda; Visiting Scholar, Saïd Businesss School, Oxford University, UK. 